\title{
Tunneling Related Party Lending Phenomenon: Empirical Study on Family Business in Indonesia
}

\author{
Ign. Novie Endi Nugroho, Rahmawati, Bandi, Agung Nur Probohudono \\ Faculty of Economics and Business, Universitas Sebelas Maret Surakarta \\ Email: novie.endinugroho@gmail.com
}

\section{A R T I C L E I N F O}

Received:

11 January 2021

Revised:

5 March 2021

Accepted:

12 March 2021

\begin{abstract}
A B S T R A C T
This study examines the effect of family end control with a pyramid structure, RPTs disclosure, internal auditors and independent commissioners on related loan tunneling in Indonesia. This study used a sample of 258 public companies listed on the Indonesia Stock Exchange from 2016-2018. This study provides empirical evidence that the final controller of the family with a pyramid structure is proven to practice tunneling through related loans. The next finding of this study is that the level of disclosure of related transactions can reduce the potential for the practice of tunneling related loans. Another important finding is the failure of the internal control mechanism by internal auditors and independent commissioners which is not able to reduce the potential for related loan tunneling practices in family companies in Indonesia.
\end{abstract}

Keywords: loans, RPT, auditors, independent

Cite this as: Nugroho, I. N. E., Rahmawati, R., Bandi, B., Probohudono, A. N. (2021). Revenue and Marketing Channel of Oyster Mushroom in Probolinggo District. Wiga : Jurnal Penelitian Ilmu Ekonomi, 11(1), 39-49. https://doi.org/ 10.30741/wiga.v11i1.651

\section{INTRODUCTION}

Related lending is a lending activity between companies that have business line relationships within a business group. This transaction was carried out with the aim of meeting financing needs and improving the performance of the group of companies. Related loans are an efficient alternative source of internal funding for business groups to anticipate underdevelopment of capital markets in emerging countries (Khanna and Palepu, 2000). Another benefit of related lending is the low asymmetry between companies conducting transactions, thereby minimizing the risk of default by the borrowing company. However, this transaction caught the attention of investors and regulators because of concerns that the parties involved in this transaction were misusing for their own interests and detrimental to the interests of other investors (Balyuk, 2014).

Related transactions are generally carried out by the board of directors or controlling shareholders by using their authority to condition the transactions they do with their subsidiaries and transfer contracts with suppliers to other companies under control (Balyuk, 2014). In affiliated companies, 
related transactions are carried out by the controlling shareholder using long-term contracts. Using this long-term contract, the controlling shareholder can reduce his business risk and can affect the performance of the affiliated company with the control rights he owns. This practice generally occurs in developing countries and countries with weak investor protection regulations regarding related party transactions (Djankov, La Porta, Lopez-de-Silanes, and Shleifer, 2008).

In Indonesia, the arrangements regarding related party transactions are specifically regulated in PSAK No. 7 (revised 2010) concerning disclosures of related party transactions. This Standard aims to ensure that the entity's financial statements contain the necessary disclosures about the possibility that the financial position and profit or loss have been affected by related party transactions, including commitments with those parties. IAI's attention to related party transactions within the scope of this accounting treatment is highly relevant, considering that the position of related entities can affect the profit or loss and financial position of other entities even if transactions with related parties do not occur.

The ownership structure of public companies in Asia is different than in America and Europe. Claessens, Djankov, and Lang (2000) found that the ownership structures of public companies in America and Europe were found to have scattered ownership, whereas in Asia, including Indonesia, they had a concentrated ownership structure. The consequence of the concentrated ownership structure is that there is a final controlling shareholder. The results of a survey by the World Bank (2010) that the majority of businesses in Indonesia are family-owned or controlled companies. This is consistent with the results of research conducted by Claessens et al. (2000) and Achmad (2008) which state that public companies in Indonesia are dominated by family businesses.

The characteristics of public company ownership in Indonesia are generally in the form of family companies with a pyramid structure (La Porta et al., 1999). Through this structure, controlling shareholders can increase their control rights beyond their cash flow rights. This increased control allows controlling shareholders to be involved directly or indirectly in the management of the company. The positive impact of this increase in control is the reduction of type I agency conflicts between principals and agents, but it opens space for the creation of type II agency conflicts, namely between controlling shareholders and non-controlling shareholders (Jansen and Mackling, 1976). This type II agency problem arises when the controlling shareholder is involved in making management decisions that have the potential to harm the interests of the non-controlling shareholders.

One solution to reducing this agency conflict is to improve the internal control mechanism by optimizing the roles of the independent commissioner and internal auditor (Jensen and Meckling, 1976). It is hoped that the increased role of internal control will be able to suppress the opportunistic behavior of managers. Findings regarding the practice of tunneling have been widely disclosed in developing countries, generally influenced by several factors, such as poor corporate governance systems (Claessens, Djankov, and Klapper, 2010; Gao and Kling, 2008; Juliarto, 2012), weak investor protection (Aharony, Wang and Yuan, 2010; La Porta, Silanes, Shleifer, and Vishny, 2000), regulatory and business environment (Liu and Tian, 2012; Juliarto, 2012), and company ownership structure (Liu and Lu, 2007; Jiang and Wong, 2003).

This study examines the effect of family end control with a pyramid structure, RPTs disclosure, Internal Auditor and Independent Commissioner on Correlated Loan Tunneling in Indonesia with control variables of company size and industrial sector. This study used a sample of 258 companies listed on the Indonesia Stock Exchange from 2016 to 2018 with a purposive sampling technique. The findings of this study are expected to broaden investors' insights in the capital market and enrich empirical studies regarding the tunneling of RPT loans to family companies in Indonesia which are still rarely found. Another important aspect of the findings of this study is to provide input to regulators regarding the level of disclosure of related transactions, the 
effectiveness of internal control mechanisms, particularly the role of independent commissioners and internal auditors, which are expected to improve the protection of non-controlling investors in the Indonesian capital market.

The consequence of the concentrated ownership structure is that there is a final controlling shareholder. La Porta et al. (1999); Claessens et al. (2000); and Faccio and Lang (2002) classify controlling shareholders into five categories, namely: 1) family, 2) government, 3) financial institutions with broad ownership, 4) companies with broad ownership, and 5) other controlling shareholders.

La Porta et al. (1999); Claessens et al. (2000); and Faccio and Lang (2002) identify family ownership based on the same last name and whether there is a marital relationship. Family members are categorized as one controlling shareholder with the assumption that they cast voting rights as a coalition (Wiwattanakantang, 2000). With a 10\% separation of control rights, the family is the most dominant controlling shareholder (La Porta et al., 1999; Claessens et al., 2000; Faccio and Lang, 2002).

The dominance of control by family controllers provides flexibility to exercise tighter corporate control, but this also has the potential to take over the company's assets from other shareholders (Faccio and Lang, 2002; Villalonga and Amit, 2006). Family controllers use a variety of means to transfer the company's wealth from free cash flow to another company where they have petty cash flow rights but with large control rights (Johnson, La Porta, Lopez-de-Silanez, and Shleifer, 2000). Controlling shareholders can transfer the company's assets to obtain private benefits through transactions between controlling shareholders and controlled companies (Gilson and Gordon, 2003).

Guo (2012) reveals that the presence of controlling shareholders with higher control rights than their cash flow rights causes a higher level of tunneling of related party transactions. Li (2010) examined tunneling performed by controlling shareholders in Chinese public companies, and found evidence of tunneling. Nugroho, Rahmawati, Bandi, and Probohudono (2020) state that $68 \%$ of public companies in Indonesia are family companies with a pyramid structure. Furthermore, Nugroho (2020) found that the final controller of the family with a pyramid structure was proven to perform tunneling through related party transactions. Based on some of the research findings, this research hypothesis can be formulated as follows: H1: The final controller of the family with a pyramid structure has a positive effect on the tunneling of RPT loans.

Disclosure of RPTs is an activity to disclose transactions between related parties in accordance with the provisions contained in PSAK 7 (revised 2010). Disclosure of transactions between related parties is carried out with the aim of providing information to parties with an interest in the company's financial statements regarding the nature and types of transactions between related parties and their effects on the company's financial statements. The measurement of RPTs disclosure refers to the research of Juvita and Siregar (2015), which is to compare the value of disclosure made by the company with the total disclosure that the company should have made. Research on the disclosure of RPTs has been carried out (Utama and Utama, 2013; Hwang, Zhang, and Zhu (2010); Juvita and Siregar, 2015) with mixed results. Utama and Utama (2013) found that the RPT measure had a positive impact on firm value when transactions involved loans from related parties and had no impact on firm value. Hwang et al. (2010) found that the higher the disclosure of RPT would increase the transparency of the company's financial statements and reduce the tendency for abusive RPT to occur. Juvita and Siregar (2015) found that the disclosure of RPTs can reduce earnings management. Based on some of the results of these previous studies, the research hypothesis can be formulated as follows: H2: The level of RPTs disclosure has a negative effect on the tunneling of RPT loans. 
Internal audit is an independent and objective assurance and consulting activity, designed to provide added value and improve the activities of an organization's operations (International Professional Practices Framework, 2011: 34). Internal auditors are formed by organizations to help achieve company goals, through a series of systematic approaches to evaluate and improve the effectiveness of risk management, control and governance processes.

The internal auditor is an independent work unit led by a Head of Internal Audit who is appointed and dismissed by the President Director with the approval of the Board of Commissioners. In carrying out its activities, Internal Audit adheres to the Internal Audit Charter established by the Board of Directors after obtaining approval from the Board of Commissioners. The Internal Audit Charter contains, among other things, the structure and position, responsibilities and authorities, code of ethics, and policies for the internal audit function.

Tong, Mingzhu, and Feng (2014) conducted a study on BUMN in China that found that the quality of internal auditors plays an important role in controlling related transactions by controlling shareholders that have the potential to harm the interests of minority shareholders. Li, Sun, and Wang (2004) state that efficient internal control can, to some extent, prevent the company's controlling behavior from committing fraudulent actions as a result of agency problems, such as related transactions, manager's opportunistic behavior, and earnings management. The main function of the internal auditor is to ensure and assist management regarding the supervisory function, improve management effectiveness and implement governance within the company to increase value and improve company performance (Tong et al., 2014). Based on the research findings above, in this study the formulation of the hypothesis can be presented as follows: H3: Internal auditors have a negative effect on the tunneling of RPT loans.

The management of companies in Indonesia adopts a two-tier board system, namely the separation of functions between the board of commissioners as an organ of the company that functions to supervise and the directors who are responsible for managing the company (UUPT No.40 of 2007). An independent commissioner is a member of the board of commissioners who is not affiliated with the board of directors, other members of the board of commissioners and controlling shareholder, and is free from business or other relationships that may affect his independence in carrying out his supervisory function. Financial Services Authority Regulation No. 33 / POJK.04 / 2014 states that the number of commissioners in the company consists of at least 2 commissioners and at least $30 \%$ of them are independent commissioners. Through the separation of functions and composition, it is hoped that the board of commissioners and independent commissioners can optimally perform their supervisory functions.

Many empirical studies examining the role of independent commissioners on tunneling have been conducted with mixed results. Several studies have found that independent commissioners have a positive effect on earnings management (Liu and Lu, 2007), and asset appropriation (Gao and Kling, 2008) has a negative effect on expropriation (Shan, 2012) and financial fraud (Chen, Chen, and Chen, 2009). ), but found no effect on executive compensation (Chen et al., 2009) and firm performance (Shan, 2012). Empirical studies regarding tunneling activity have been carried out in various countries with mixed findings. Juliarto (2012) states that governance mechanisms in the form of foreign ownership and independent boards of commissioners in developing countries are not effective factors in controlling tunneling activities. Hastori, Sembel, and Maulana. (2015) also found that independent commissioners are not a significant factor in reducing expropriation practices. Based on some of the results of these previous studies, the research hypothesis can be formulated as follows: H4: The proportion of independent commissioners has a positive effect on RPT loan tunneling. 


\section{METHOD}

This study uses sample data on nine company sectors listed on the Indonesia Stock Exchange, except for the banking sub-sector. The data was collected by using purposive sampling method. This study uses 258 sample companies listed on the Indonesia Stock Exchange from 2016 to 2018. Measurement of the dependent variable tunneling loan RPTs refers to Nugroho et al. (2020) which is measured by the difference between accounts receivable (short term and long term) and debt (short term and long term) divided by total assets. Short-term receivables used are other receivables except trade receivables, while long-term receivables used are related party receivables. Information on short-term debt used is other debt except trade payables, while longterm debt is used for related party debt. The final control data for the family was obtained by Globe Asia (www.globeasia.com) which published data on 100 business groups in Indonesia in 2018. Unique data on the ownership structure of the pyramid was traced from company financial reports, IPO reports and collaborative company websites to compile a sample company business group structure. Measurement of the level of disclosure of RPTs refers to the measurement used by Utama and Utama (2013) which compiled 10 questionnaires based on the six categories stipulated in POJK VIII.G.7 concerning Guidelines for the Presentation of Financial Statements, particularly on related party transactions. Data on internal auditors and independent commissioners were obtained from the company's annual report for 2016-2018.

\section{RESULTS AND DISCUSSION}

Testing the hypothesis of this study using the binary logistic regression test to test 2 groups of tunneling and non-tunneling company classifications. The main regression model of this study is presented as follows: $T_{-} R P T s L_{i, t}=\alpha_{0}+\beta_{1} . U L T M \_P Y R M D_{i, t}+\beta_{2} . D S C L_{i, t}+\beta_{3} . I A U D_{i, t}+\beta_{4}$ $I_{I N D E P}+\beta_{5} . S I Z E_{i, t}+\beta_{7 .} S E C_{i, t}+\varepsilon_{i, t}$

Where T_RPTsLt is the tunneling of RPTs loans. ULTM_PYRMD is the ultimate controller of the family via a pyramid ownership structure. DSCL is the disclosure of RPTs. IAUD is an internal auditor and INDEP is an independent commissioner. This study uses the SIZE control variable, namely company size and the SEC is the industrial sector.

Table 1 Panel A presents descriptive statistics of all research samples $(\mathrm{N}=258)$. The results of this test indicate that the dependent variable T_RPTsL has a positive mean value $(14.17 \%)$ which indicates an indication of the tunneling behavior of the sample companies. The ULTM_PYRMD variable has a positive mean value $(6.09 \%)$. This shows that the final controller of the family with a pyramid structure has an average control right that is higher than the right to cash flow by $6.09 \%$. The DSCL variable has an average value of $62.57 \%$. These findings indicate that the average sample company has a disclosure level of $62.57 \%$ of the supposed disclosure. The IAUD variable has an average value of 4.88. These results indicate that on average the sample companies have met the minimum requirements stipulated in POJK No. 56 / POJK.04 / 2015 that the minimum limit for a public company internal auditor is 1 auditor. The results of the INDEP variable test showed an average value of $42.67 \%$. These results indicate that the average sample company has met POJK N0.33 / POJK.04 / 2014 that the minimum proportion of independent commissioners in public companies is $30 \%$ of the board of commissioners. The test results of the SIZE control variable showed an average value of 12.72 . This value indicates that the average sample company has a large size, which is above 10.00 .

Table 1 Panel B presents the frequency distribution and independent sample t-test for the SEC variable, tunneling and non-tunneling company groups, as well as end-family and non-family controllers. The results of the industrial sector variable frequency distribution (SEC) test results show that of the 258 sample companies, 117 companies (45.30\%) are included in the SDA and 
Manufacturing companies category (1) and the remaining 141 companies (54.70\%) are included in other company groups.

In the test of the two categories of tunneling and non-tunneling companies, it shows that of the 258 sample companies, 146 companies $(56.60 \%)$ are included in the tunneling company category (1) and the remaining 112 companies $(43.40 \%)$ are included in the non-company group. -tunneling (2). Based on the results of the t-test, the t-statistic value is 2.503 with a significance level of 0.013 and a mean difference value of $29.58 \%$. These results indicate a significant difference $(0.013$ $<0.05$ ) between dummy 1 (tuneling) and dummy 0 (non-tunneling) in the tunneling activity of RPTs loans.

In the test of two categories of family company groups and other than family companies, it shows that of the 258 sample companies, 186 companies (72.10\%) are included in the family company category (1) and the remaining 72 companies (27.90\%) are included in the company group other than family company (2). Based on the results of the t-test, the t-statistic value was obtained at 8.265 with a significance level of 0.000 and a mean difference of $2.39 \%$. These results indicate a very significant difference $(0.000<0.01)$ between dummy 1 (family firm) and dummy 0 (nonfamily firm) in the category of company groups.

Table 1: Descriptive Statistics and Independent Sample T-Test of all Observations $(\mathbf{N}=258)$ Panel A: Descriptive Statistics of Research Variables

\begin{tabular}{llllll}
\hline & N & Min & Max & Mean & SD \\
\hline T_RPTsL $(Y)$ & 258 & $-0,55$ & 11,99 & 0,1417 & 1,0821 \\
ULTM_PYRMD $\left(\mathrm{X}_{1}\right)$ & 258 & 0,00 & 0,71 & 0,0609 & 0,1413 \\
DSCL $\left(\mathrm{X}_{2}\right)$ & 258 & 0,22 & 0,89 & 0,6257 & 0,0683 \\
IAUD $\left(\mathrm{X}_{3}\right)$ & 258 & 1,00 & 6,00 & 4,8798 & 0,2244 \\
INDEP $\left(\mathrm{X}_{4}\right)$ & 258 & 0,00 & 1,00 & 0,4267 & 2,5816 \\
SIZE $\left(\mathrm{X}_{7}\right)$ & 258 & 9,2503 & 14,2534 & 12,7240 & 0,0379 \\
\hline
\end{tabular}

Panel B: Frequency Distribution and Independent Sample T-Test $(\mathbf{N}=1,340)$ Industrial Sector (SEC)

\begin{tabular}{|c|c|c|c|}
\hline & SDA \& Manufaktur (1) & Others (0) & Total \\
\hline SEC & 117 & 141 & 258 \\
\hline$\%$ & 45,30 & 54,70 & 100 \\
\hline \multicolumn{4}{|c|}{ Tunneling Related Loans (T_RPTsL) } \\
\hline & Tunneling Firms (1) & Non-Tunneling Firms (0) & Total \\
\hline 2 Group & 146 & 112 & 258 \\
\hline$\%$ & 72,10 & 27,90 & 100 \\
\hline T_RPTsL-1 (mean) & 0,270142 & $-0,025719$ & \\
\hline$N$ & 146 & 112 & 258 \\
\hline$t$-statistic & 2,503 & & \\
\hline Mean difference & 0,2958 & & \\
\hline$\rho$-value & 0,013 & & \\
\hline \multicolumn{4}{|c|}{ Ultimate Owner (ULTM) } \\
\hline & Family Firms (1) & Non-Family Firms (0) & Total \\
\hline ULTM & 186 & 72 & 258 \\
\hline$\%$ & 72,10 & 27,90 & 100 \\
\hline T_RPTsL-1 (mean) & 0,127691 & $-0,177913$ & \\
\hline$N$ & 186 & 72 & 258 \\
\hline t-statistic & 8,265 & & \\
\hline Mean difference & 0,0239 & & \\
\hline$\rho$-value & 0,000 & & \\
\hline
\end{tabular}


Information: T_RPTsL= Tuneling Loan RPTs; ULTM_PYRMD= Final Control of the Family with a Pyramid Structure; $D S C L=$ Disclosure RPTs; $I A U D=$ Internal Auditor; INDEP= Independent Commissioner; SIZE = Company Size; $S E C=$ Industrial Sector with Pyramid Structure; ULTM= Enterprise End Control.

Table 2 below shows the Pearson correlation across samples $(\mathrm{N}=258)$. The correlation between T_RPTsL and ULTM_PYRMD is positive and significant at the $1 \%$ level. The correlation between T_RPTsL and DSCL shows a negative correlation and is very significant at the $1 \%$ level. Different results were found in the T_RPTsL correlation test with the IAUD and INDEP which showed a positive and insignificant correlation.

The results of the T_RPTsL correlation test and the control variable SIZE show a negative and very significant correlation at the $1 \%$ level, on the other hand, the SEC variable shows a negative but insignificant correlation.

Table 2: Pearson Correlation the entire Sample (N: 258)

\begin{tabular}{lccccccc}
\hline & $T_{-} R P T s L$ & $\begin{array}{c}\text { ULTM_ } \\
\text { PYRMD }\end{array}$ & DSCL & IAUD & INDEP & SIZE & SEC \\
\hline T_RPTsL & 1 & & & & & & \\
ULTM_PYRMD & $0,264^{* *}$ & 1 & & & & & \\
DSCL & $-0,164^{* *}$ & $-0,068$ & 1 & & & & \\
IAUD & 0,000 & $-0,099$ & 0.001 & 1 & & & \\
INDEP & 0,040 & 0,015 & -0.057 & $-0,017$ & 1 & & \\
SIZE & $-0,475^{* *}$ & $-0,138^{*}$ & -0.015 & $0,250^{* *}$ & 0.181 & 1 & \\
SEC & $-0,005$ & $-0,063$ & $0,211^{* *}$ & -0.024 & -0.025 & -0.107 & 1 \\
\hline
\end{tabular}

Information: *; **;indicates significant < at the level 5\%; and 1\% (2-tailed).

This analysis is used to determine predictors that differentiate between tunneling and nontunneling-indicated corporate behavior. Table 3 presents the results of the binary logistic regression test for 258 samples. The test results showed that the psudeo chi-square value was 345.319 with a p-value of 0,000 and the psudeo negelkerke $\mathrm{R}$ square was $16.7 \%$, while the accuracy of the logistic regression model was $67.4 \%$. Table 3 presents a summary of the results of the binary logistic regression test. The results of testing the final control variable of the family through a pyramid structure (ULTM_PYRMD) show a positive and very significant regression coefficient at the $1 \%$ level. This result supports $\mathrm{H} 1$ which states a positive relationship between ULTM_PYRMD and T_RPTsL. The RPTs disclosure test (DSCL) shows a negative and very significant regression coefficient at the $1 \%$ level. This result supports $\mathrm{H} 2$ which states a negative relationship between DSCL and T_RPTsL. Insignificant results are shown in the testing of internal auditors (IAUD) and independent commissioners (INDEP) on related loan tunneling. These results cannot support Hypothesis 3 and Hypothesis 4.

The T_RPTsL test results with the SIZE control variable showed a positive and significant regression coefficient, but the industrial sector variable (SEC) showed insignificant results. 
Table 3: Binary Logistic Regression 2 Group of Companies: Tunneling dan Non-Tunneling $(\mathrm{N}=\mathbf{2 5 8})$

\begin{tabular}{|c|c|c|c|}
\hline \multicolumn{4}{|c|}{ Dependent Variabel: T_RPTsL-1 } \\
\hline Variables & Exp. Sign & Coefficient & p-value \\
\hline Constant & & -3.281 & 0.165 \\
\hline ULTM_PYRMD (H1) & + & 0.829 & $0.006 * * *$ \\
\hline $\operatorname{DSCL}(\mathrm{H} 2)$ & - & -3.609 & $0.000 * * *$ \\
\hline IAUD (H3) & - & 0.001 & 0.971 \\
\hline INDEP (H4) & - & -1.426 & 0.178 \\
\hline SIZE & & 0.457 & $0.014 * *$ \\
\hline SEC & & 0.049 & 0.862 \\
\hline \multicolumn{4}{|c|}{ Notes: $* ; * * ; * *$ indicates significant $<$ at the level.10\%; $5 \%$; and $1 \%$ (2-tailed). } \\
\hline Chi-Square & & 34.31 & \\
\hline Significant & & 0.00 & \\
\hline Hosmer and Lemeshow Test & & 5.78 & \\
\hline Significant HL test & & 0.67 & \\
\hline Percentage Correct & & $67.4^{c}$ & \\
\hline Negelkerke R Square & & 16.7 & \\
\hline
\end{tabular}

\section{CONCLUSION}

The purpose of this study is to examine the relationship between family end controllers through a pyramid structure, RPTs disclosure, internal auditors and independent commissioners on the relationship between loan tunneling and the control variable firm size and the industrial sector.

The results of hypothesis 1 testing indicate that the final control of the family through the ownership structure of the pyramid has a positive and very significant effect on related loan tunneling. This finding can be interpreted that related loans in business groups with a pyramid ownership structure tend to be used by the controlling shareholder of the family's end to carry out the practice of tunneling related loans which is detrimental to the interests of minority shareholders. This finding also confirms the type II agency theory that the separation of control rights and cash flow rights in concentrated ownership triggers agency conflicts between controlling shareholders versus minority shareholders. The dominance of control that is owned by controlling shareholders in business groups with a pyramid ownership structure can be freely used to control the company's management, either directly or indirectly.

The results of hypothesis testing 2 show that the disclosure of RPTs has a negative and very significant effect on related loan tunneling. This finding can be explained that the higher the company makes related transaction disclosure, the more likely it is to reduce the possibility of tunneling related loan practices carried out by the end-of-family controller. Based on the results of statistical tests (Table 2), the average level of disclosure of RPTs for the sample companies of $62.57 \%$ has met the minimum RPTs disclosure limit, which is 6 out of 10 disclosure items in accordance with PSAK 7 (revised 2010). These findings indicate that the higher the disclosure of RPT, the greater the transparency of the company's financial statements and reduce the tendency for abusive RPT to occur (Hwang et al., 2010). These findings at the same time confirm agency theory that through an effective supervisory mechanism, in this case, internal control by internal auditors can reduce the opportunistic behavior of company management which is controlled by the final controller of the family. 
The results of hypothesis 3 testing indicate that the internal auditors have no effect on the tunneling of RPTs loans carried out by the end-of-family controllers. This finding can be interpreted even though the average number of internal auditors of the sample companies in this study shows an average of 4.8 which means that they have met the minimum requirements set out in POJK No. 56 / POJK.04 / 2015 that the minimum limit for internal auditors of public companies is 1 auditor, but the presence of internal auditors is not effective enough to control tunneling practices through RPTs loans which are carried out by the final controller of the family. These findings become interesting things in this study. Although in carrying out their duties the internal auditor has a clear mandate which is stated in detail and firmly in the Internal Audit Charter, but the strong control right of the family's final controller as the central power of decision making and management policy causes the function and role of the internal auditor to be ineffective and is limited to comply only with regulatory provisions.

The results of hypothesis testing 4 found that the independent commissioners had no effect on the tunneling of RPTs loans carried out by the end-of-family controllers. This finding can be interpreted even though the average number of independent commissioners in the sample companies is $42.67 \%$, which means that they have met the minimum proportion stipulated in fulfilling the OJK Regulation No. 33 / POJK.04 / 2014 amounted to 30\% of the board of commissioners, but the existence of independent commissioners was not effective enough to control tunneling practices through RPTs loans that were carried out by the final controller of the family. These findings become interesting things in this study. Although the process of selecting independent commissioners in Indonesia is sufficiently well regulated in Law Number 40 of 2007 as well as improved regulations through Bapepam Regulation Number IX.I.5 of 2011, in reality the existence of independent commissioners in family companies only meets formal requirements and does not. intended to streamline corporate governance practices. Meanwhile, the final controller of the family has a strong dominance of control so that the function and role of the independent commissioner becomes ineffective.

The implications of this research are: First, the Government can encourage OJK as the regulator of the Indonesian capital market to make the various existing regulations more effective, especially those related to disclosure of related transactions. Through firm law enforcement, it is hoped that it can reduce various negative impacts related to related party transactions which are often used by the end-of-family controllers to carry out illegal transactions that have the potential to harm the interests of non-controlling shareholders. The implication of these two studies is that the government through related institutions can continue to encourage efforts to implement corporate governance practices in public companies in Indonesia. Through this improvement in the quality of corporate governance, it can strengthen and make the role of internal auditors and independent commissioners effective in carrying out their supervisory functions so as to reduce the occurrence of related loan tunneling practices in Indonesia.

\section{REFERENCE}

Achmad, T. (2008). Concentrated Family Ownership Structures Weakening Corporate Governance: A Developing Country Story, The Case of Indonesia Companies. Jurnal Manajemen Akuntansi \& Sistem Informasi, 8 (2): 118-134.

Aharony, J., J. Wang, dan H. Yuan. (2010). Tunneling as an Incentive for Earnings Management During The IPO Process in China. Journal of Accounting and Public Policy, 29 (1):1-26.

Balyuk, Tetyana. (2014). An Empirical Study of Related-Party Lending. Available at SSRN: https://ssrn.com/abstract=2803750.

Claessens, S., S. Djankov, L. Klapper. (2003). Resolution of Crporate Distress in East Asia. Journal of Empirical Finance, 10: 199-216.

Claessens, S., S. Djankov, dan L.H.P. Lang. (2000). The Separation of Ownership and Control in East Asian Corporations. Journal of Financial Economics, 58 (1-2): 81-112. 
Chen, Y., C-H. Chen, dan W. Chen. (2009). The Impact of Related Party Transactions on the Operational Performance of Listed Companies in China. Journal of Economic Policy Reform, 12 (4): 285-297.

Djankov, S., R. La Porta, F. Lopez-de-Silanes, dan A. Shleifer. (2008). The Law and Economics of Self-Dealing. Journal of financial economics, 88 (3): 430-465.

Faccio, M., dan L.H.P. Lang. (2002). The Ultimate Ownership of Western European Corporations. Journal of Financial Economics, 65(3): 365-395.

Gao, L., dan G. Kling. (2008). Corporate Governance and Tunneling: Empirical Evidence from China. Pacific-Basin Finance Journal, 16 (5): 591-605.

Gilson, R., dan J.N. Gordon. (2003). Controlling Controlling Shareholders. University of Pennsylvania Law Review, 15 (2): 785-850.

Guo, F. (2012). Related Lending Evidence of Tunnelling and Propping in China. Working Paper. School of Economics and Finance, Australia: Curtin University of Technology.

Hastori. S.H,; R. Sembel; dan T.N.A Maulana. (2015). Agency Costs, Corporate Governance and Ownership Concentration: The Case of Agro-industrial Companies in Indonesia. Asian Social Science, 11 (18): 311-319.

Hwang, C. Y., S. Zhang, and Y. Zhu. (2010). Related Party Transactions in China Before and After the Share Structure Reform. China Accounting and Finance Review International Symposium, Nanjing, China,

International Profesional Practice Framework (IPPF). (2017). Greenwood Blvd, Suite 401 Lake Mary, FL 32746 USA.

Jensen, M., dan W. Meckling. (1976). Theory of The Firm: Managerial Behaviour, Agency Costs and Ownership Structure. Journal of Financial Economics, 3 (4): 305-360.

Juvita, D., dan S.V. Siregar. (2015). Pengaruh Corporate Governance terhadap Hubungan Besaran dan Pengungkapan Transaksi Pihak Berelasi dengan Manajemen Laba : Studi Empiris Perubahan PSAK no 7, Jurnal Akuntansi dan Auditing 10 (1) : 45 - 67.

Johnson, S., R. La Porta, F. Lopez-de-Silanez, dan A. Shleifer. (2000). Tunneling. American Economic Review, 90 (2): 22-27.

Juliarto, A. (2012). Tunneling: Related Party Transactions of ASEAN Listed Firms. Doctoral Thesis, Australia: Curtin University of Technology, Perth.

Jian, M., dan T.J. Wong. (2003). Earnings Management and Tunneling Through Related Party Transactions: Evidence from Chinese Corporate Groups. Working Paper. Hong Kong: University of Science and Technology.

Khanna, T., dan K. Palepu. (2000). Emerging Market Business Groups, Foreign Intermediaries, and Corporate Governance. Concentrated corporate ownership. Chicago, Illinois, U.S.A: University of Chicago Press.

Li. ZQ., Z. Sun, dan ZW. Wang. (2004). Tunneling and Ownership Structure of a Firm: Evidence from Controlling Shareholder's Embezzlement of listed Companies' Funds in China. Account Review, 12: 3-13.

Li, G. (2010). The Pervasiveness and Severity of Tunneling by Controlling Shareholders in China. China Economic Review, 21 (2): 310-323.

La Porta, R., F. Lopez-de-Silanes, dan A. Shleifer. (1999). Corporate Ownership Around the World. Journal of Finance, 54 (2): 471-517. , dan R.W. Vishny. (2000). Investor protection and corporate governance. Journal of Financial Economics, 58 (1-2): 3-27.

Liu, Q., dan Z. Lu. (2007). Corporate governance and earnings management in the Chinese listed companies: A tunneling perspective. Journal of Corporate Finance, 13(5): 881-906. ., dan Tian. (2012). Controlling Shareholders Expropriation and Firms Leverage Decision: Evidence from Chinese Non-Tradable Share Reform. Journal of Corporate Finance, 18(4): 782-803.

Nugroho, N.E., Rahmawati., Bandi, dan A.N. Probohudono. (2020).Tunneling pinjaman berelasi: studi empiris pada perusahaan keluarga di Indonesia. Disertasi. Universitas Sebelas Maret Indonesia. 
Peraturan Otoritas Jasa Keuangan POJK No. 33/POJK.04/2014

Peraturan Otoritas Jasa Keuangan POJK No. 56/POJK.04/2015 bahwa batas minimal auditor internal perusahaan publik adalah 1 orang auditor.

Shan, Y. G. (2012). Can Internal Governance Mechanisms Prevent Asset Appropriation? Examination of Type I Tunneling in China. Financial Markets and Corporate Governance Conference.

Tong, Y., W. Mingzhu, dan X. Feng. (2014). Internal Control, Related Party Transactions and Corporate Value of Enterprises Directly Controlled by Chinese Central Government. Journal of Chinese Management, 1 (1): 1-14.

Utama, C.A., dan S. Utama. (2013). Corporate Governance, Size and Disclosure of Related Party Transactions, and Firm Value: Indonesia Evidence, International Journal of Disclosure and Governance $11: 341-365$.

Undang-Undang No.40 tahun 2007 tentang Perseroan Terbatas

Villalonga, B., dan R. Amit. (2006). How do Family Ownership, Control, and Management Affect Firm Value? Journal of Financial Economics, 80(2): 385-417.

Wiwattanakantang, Y. (2000). The Equity Ownership Structure of Thai Firms. Working Paper, Kunitachi, Tokyo: Hitotsubashi University. 